THURSDAY, AUGUST r, IS78

\section{THE ECLIPSE OF THE SUN}

$7 \mathrm{HE}$ following telegram was received from $\mathrm{Mr}$. Lockyer at the moment of going to press. It contains the fullest account of the results of the Eclipse, and of the conclusions arrived at by some of the most eminent of the observers engaged on it, which has yet been published :-

Corona smaller and less brilliant than in 1869 and $187 \mathrm{I}$. Hydrogen faint in corona. Generally invisible, as was also the case in 1874 . Ranyard's polarisation confirmed Young's law, both(?)and lines brilliant. Corona probably photographed in Siam (?). Fluorescent eyepiece worked well. Bright line near $B$; heat line in ultra red by thermopile. Watson's Vulcan, Right ascension $8^{\circ} 26^{\prime}$, declination $18^{\circ}$ N. Result-lower temperature of corona gas, as confined to chromosphere; almost entirely continuous spectrum, isolated from gaseous spectrum. Corona changes with sun-spots, and prominences increased. Continuation of absorption with deficit in ejected hot matter induces solar radiation. Young, Watson, Draper, Loskyer cable above.

The following telegram appears in the Daily News of yesterday from its special correspondent at Rawlings, Wyoming, U.S., under date July 29 :-

The eclipse bas been most satisfactorily observed at all the northern stations, and at all the southern ones from which news has been received up to the present time.

The corona was markedly different from those observed in 1869,1870 , and $187 \mathrm{r}$, and this year the observations have demonstrated the great variation in the structure and condition of the sun's outer atmosphcre when there are most and fewest spots on his disc. The corona was small, of a pearly lustre, and the indications of definite structure were limited to two portions. Several long rays were seen, and Prof. Newcomb, who had erected a screen on a high pole, thinks he detected the zodiacal light extending six degrees from the sun. Prof. Draper, who used a Rutherfurd grating two inches square and a camera of large aperture, and Mr. Lockyer, who placed a small grating in front of an ordinary portrait camera, both obtained photographs of the spectrum of the corona. A continuous spectrum only was recorded, and in ordinary spectroscopes the bright lines usually seen were altogether absent. Mr. Lockyer, who observed with a simple grating, saw no rings.

All these are so many indications of a wonderful change since $187 \mathrm{I}$, and there is great probability that the substance which gives rise to the continuous spectrum is not that which produces any of the lines.

Prof. Newcomb's party and Prof. Barker made a careful search for the dark lines in the corona, but none were observed. Prof. Young has telegraphed that there were no lines observed in the ultra violet at Denver. It would appear, therefore, that he also bas obtained photographic evidence of a continuous spectrum. The radial polarisation observed in $187 \mathrm{I}$ has been confirmed by Prof. Holden.

A new use of the eclipse has been introduced on this occasion. Professors Newcomb, Watson, Holden, and others have included a search for intramercurial planets

Vol. xyili.-No. 457 in their programme, and Prof. Watson has been fortunate enough to detect a body of four and a half magnitude near the sun, which certainly is neither a known star nor a planet.

Every facility has been afforded to the astronomers, and a fourth station along the northern line crossing the belt of totality was at the last moment organised by the Union Pacific travelling photographic car being run to a point between the Eclipse camps at Separation and Preston.

The tasimeter, the new instrument on which $\mathrm{Mr}$. Edison has been working unceasingly here, has proved its delicacy. During the eclipse he attached Thomson's galvanometer, the index being set to zero, when the telescope carrying the tasimeter was pointed several degrees from the sun. The point of light rapidly left the scale, when the corona was brought upon the fine slit by which the tasimeter itself was protected. There was no chromosphere to speak of, and only one prominence, like the horn observed in 1868 , but very dim.

\section{OUR NATURAL HISTORY COLLECTIONS}

O $\mathrm{N}$ referring to the "Bill to enable the Trustees of the British Museum to remove Portions of their Collection," our readers will see that our correspondent, "Naturalist," in our last issue (p. 328), is correct in supposing that this measure contemplates no change whatever in the administration of the natural history collections when placed on their new site in South Kensington. The fourth clause of the Bill expressly reserves all the "rights, powers, duties, and obligations" of the fifty trustees, except as regards the mere removal of the portions of the collections specified in the schedule. And we must agree with our correspondent that this measure will be directly contrary to the opinion of many of our leading naturalists, and to the recommendations of the Royal Science Commission.

As regards the first point, it is only necessary to refer to the memorial presented to the Chancellor of the Exchequer in I866, when the subject of the removal of the natural history collection was under discussion. The memorial, which was drawn up primarily in support of the removal of the natural history collections from the rest of the British Musetum, and is signed by $\mathrm{Mr}$. Bentham, Mr. Darwin, Sir J. Hooker, Prof. Huxley, and other well-known names, states that in the opinion of the memorialists "it is of fundamental importance to the progress of the natural sciences in this country that the administration of the natural history collections should be placed under one officer, who should be immediately responsible to one of the Queen's ministers." The Bill as drawn proposes to leave the natural history collections exactly as they are, under the rule of fifty trustees responsible to $n o$ one but to themselves.

Let us now turn to the Fourth Report of the "Royal Commission on Scientific Instruction and the Advancement of Science," issued in 1874 , in which the affairs of the British Museum, and more especially of the natural history collections belonging to it, are discussed. After an exhaustive account of the circumstances of the case and an analysis of the evidence given before then by the 
leading naturalists of the day on the subject, the Royal Commissioners came to the following conclusions :-

I. That the occasion of the removal of these collections to the new buildings now being erected at South Kensington for their reception be taken advantage of to effect a change in the governing authority and official administration of that division of the museum.

2. That the director of the natural history collections should be appointed by the Crown, and should have the entire administration of the establishment under the control of a Minister of State, to whom he should be immediately responsible.

Now it is hardly necessary to point out that if the Bill before the House of Commons be passed in its present state (whereby all "the rights, powers, duties, and obligations" of the Trustees of the British Museum are expressly reserved), the recommendations of the Royal Commissioners will be treated as so much waste paper. If the Government appoints a Commission of the best men of the country to advise them on a subject of which they know nothing, it seems to us to be hardly civil to allow an Act of Parliament to be passed in the teeth of their deliberate recommendations without even taking the trouble to explain why these recommendations are not to be carried into effect. Yet this is what is now proposed to be done.

\section{HULL'S GEOLOGY OF IRELAND}

The Physical Geology and Geography of Ireland. By. Edward Hull, M.A., F.R.S. (London: Stanford, 1878.) THE great map of the veteran Sir Richard Griffith, 1 followed by the detailed labours of other geologists, especially of the Geological Survey, and of its lamented director, the late J. B. Jukes, has explained the general geological structure of Ireland, and sketched, partly in outline, partly in considerable detail, the curious problems which that structure suggests. As yet, however, the abundant published information to be gleaned from papers and memoirs regarding Irish geology lies chiefly scattered through the Transactions of various scientific societies, and the Explanations of the Survey. Some of these publications are not nearly so widely known as they deserve to be, or as they assuredly would be if it were more easy for geological students in general to procure a reading of them. $\mathrm{Mr}$. Hull has, therefore, done good service in preparing this little handbook to the geology and geography of Ireland. It is a most useful compendium of information, and its utility is greatly enhanced by the references to those works and paper's where the subjects he discusses are more fully treated.

The volume is divided into three parts. In the first of these the author gives a digest of what is known regarding the geological formations of Ireland. In treating of the palæozoic rocks, he follows Harkness and others in regarding the metamorphic rocks of the north-western counties as the general equivalents of the unaltered Lower Silurian masses of the rest of the island, thus identifying both groups of rocks with those, which occupy a similar position in Scotland. In this he is undoubtedly correct, and is quite justified by the sections published by Murchison and others. In these days, however, when almo.t every dictum of our fathers is called in question, and when able observers on both sides of the Atlantic are loudly proclaiming that they can find no true palæo. zoic gneiss and schist anywhere; when Alpine rocksonce devoutly regarded as metamorphosed Cretaceous strata-have been pushed back and back till their enemies will not let them have a footing among any even of the palæozoic formations, it certainly would be a good and serviceable piece of work to fix, if possible, by means of fossils, the horizon of the quartzites and limestones of Donegal, and to demonstrate, by numerous transverse sections, that these rocks pass truly, and with no deceptive overturn, beneath the younger gneissose and schistose masses. In Prof. Hull's necessarily brief summary he does scant justice to the Old Red Sandstone. To some extent he makes up for this by the greater fulness of his account of the Carboniferous system, to which he gives considerable interest by the parallelism, suggested by his long experience in Lancashire and elsewhere, between the established divisions of the system in England and the grouping which he has been able to recognise in Ireland. The fragments of Permian and Mesozoic deposits in the north of Ireland are duly mentioned; a more detailed description is given of the huge volcanic plateau of Antrim, and the successive stages of its history; while the Glacial and Post glacial formations receive tolerably ample illustration.

Having laid his foundation of facts, Mr. Hull proceeds, in Part II., to build upon it his explanation of the present physical geography of Ireland. Beginning with the mountains he arranges them in groups, and points out in each case the evidence of their age. The remark just made regarding the metamorphic rocks of Donegal may be repeated here in reference to the alleged age of these north-western mountains. Of course as Upper Silurian rocks lie against them and contain conglomerates derired from them, these heights must be far older than Upper Silurian times. The author assigns them to a long unrepresented interval between the Upper and Lower Silurian periods-a date to which the corresponding Scottish Highlands have also been referred. In dealing with the Wicklow Highlands so admirably worked out by Jukes and his colleagues, Mr. Hull suggests that as the granite there was certainly protruded before the Old Red Sandstone had been laid down, it may even have been earlier than Upper Silurian time, and "therefore synchronous with the mountains of Donegal, Mayo, and Galway." But the Old Red Sandstone of the South of Ireland, thick though it be, seems to represent only the upper member of that system. The vast period of the Lower Old Red Sandstone, so rife elsewhere in subterranean movements and volcanic outbursts, is not known in the south of the island, unless. we may conjecture the Wicklow granite to belong to that epoch. The numerous and characteristic ridges and isolated eminences which in the south-western counties and in the central plain rise out of the Carboniferous plain, often with a central core of contorted Silurian rocks, are assigned to an interval of terrestrial disturbance between the Carboniferous and Permian periods. The evidence for this conclusion is fragmentary and has been skilfully marshalled into form by the author; but it cannot be regarded as by any means conclusive. Yet more uncertain is the reference of the Mourne Mountains to the Permian period. That 